\title{
Preliminary report of archaeological research at the Kastel site in Banja Luka in 2019
}

useum of Republic of Srpska

Museum of Republic of Srpska Banja Luka, University of Banja Luka, Republic of Srpska S

Belgrade Archeological Institute, University of East Sarajevo, Serbia slavisa.r.peric@gmail.com

Kompleks trdnjave Kastel v središču Banjaluke, na sotočju rek Crkvena in Vrbas, je poligonalne oblike in zajema površino $26.610 \mathrm{~m}^{2} \mathrm{v}$ notranjosti in $21.390 \mathrm{~m}^{2}$ izven obzidja trdnjave. Trdnjavo sestavljajo trije neenaki deli notranjega prostora ali »dvorišča «, devet bastij, štirje stolpi in trije vhodi. Zgrajena je bila iz pravokotnega obdelanega kamna v nepravilnem slogu z dodano apneno malto. Sestavni del obrambnega sistema trdnjave je bil jarek, širok 20-30 m, ki je obdajal Kastel na vseh kopenskih straneh in je danes zasut. Prva arheološka odkritja segajo v leti I895 in 1924, medtem ko so bila arheološka izkopavanja izvedena v več fazah od leta 197ı do 1988. Do danes so dokumentirani ostanki iz poznega paleolitika (Gravettien), neolitika in eneolitika (badenske in vučedolske kulture) ter pozne bronaste in železne dobe. Ostanki temeljev rimskih zidov, bronaste fibule in številne novčne najdbe iz obdobja od 2. do 4. stoletja najverjetneje pripadajo rimskemu kastrumu, medtem ko so na območju dvorišča III odkrili keramiko iz zgodnjega srednjega veka, ki jo lahko povežemo s slovansko naselbino od 9. do I2. stoletja.

Ključne besede: geofizikalno snemanje, revizijska izkopavanja, multiperiodno najdišče

Situated at the heart of Banja Luka city centre, at the mouth of the river Crkvena in Vrbas, the Kastel Fortress is a complex, polygonal in shape and occupying an area of 26,610 $\mathrm{m} 2$ inside and 21,390 $\mathrm{m} 2$ outside the fortification walls. The existing fortress consists of three parts of the inner space of different sizes, the "courtyards", nine bastions, four towers and three entrance gates. It is constructed of rectangular worked stone, in irregular style, with lime mortar added. An integral part of the defense system of the fort was a 20-30 m wide ditch circling the Kastel fortress and now fully backfilled. The first archeological discoveries date from 1895 and 1924 , while archaeological excavations were carried out in stages from 1971 to 1988. The findings range in date from the Late Paleolithic (Gravettien), Neolithic and Eneolithic (Baden and Vučedol cultures), and the Late Bronze and Iron Age. Remains of Roman walls, bronze fibulae, and numerous finds of coins from the 2 nd to 4 th century AD probably deriving from the Roman castrum. Pottery recovered from investigations into the Courtyard III was dated to the early medieval period, possibly corresponding to the Slavic settlement from the period between 9 th and $\mathrm{I} 2$ th century. Keywords: geophysical research, revision excavation, multilayered site

History of Kastel fortress and of archaeological research

T he Kastel fortress is located on a small hill on the left bank of the Vrbas river and next to the small river Crkvena which flows into the Vrbas on the north-western side of the fortress (Figure $\mathrm{I}$ ). The small hill was a suitable strategic point and has been inhabited since prehistoric times. The oldest discoveries (flint tools) date back to the Gravettien period, ie. the latest stages of the Upper Palaeolithic 


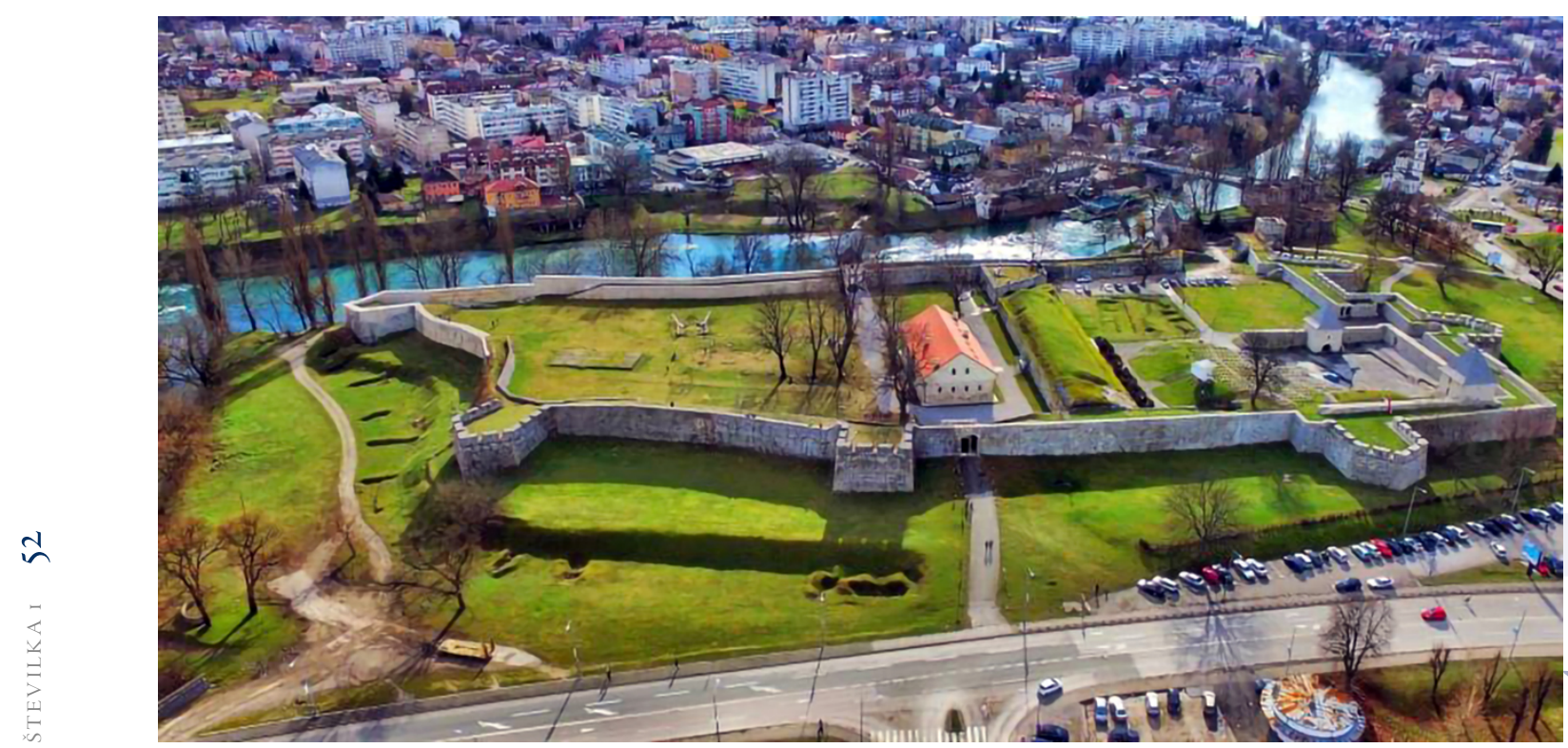

Figure I Location of the Kastel fortress.

in northern Bosnia. The pottery recovered from the fortress was dated to the Neolithic, while from the Eneolithic (Copper Age) ceramics from the Baden cultural group and a small number of Vučedol culture pottery fragments were discovered. Within the ramparts, archaeological material dating from the Late Bronze and Iron Age was also found. Based on the discoveries, it was interpreted that during antiquity (Roman period) there was an ancient settlement called Castra, in which there was a travel station (mansio), a military camp (castrum), a civilian settlement adjacent to the camp (canabae) and a beneficiary station (statio). It belonged to the territory of the Upper Pannonia province, and the area was inhabited by the Oseriates tribe. The settlement of Castra was located on communication that departed from Salona (Solin), which in that period used to represent the political centre of the Roman province of Dalmatia, to the Seritius (Bosanska Gradiška), the port on the Sava in the Pannonia province.

In the mid-eighteenth century, according to the travelogue of Evliya Çelebi as well as other travel writers, two cities were mentioned in Banja Luka; one in Gornji Šeher and the other in Don- ji Šeher (area of the present Kastel). Although the name Banja Luka was firstly mentioned in 1494 , it is not known where the fortress of Banja Luka was located. In I554, Banja Luka became the base of the Bosnian sanjak-bey (-commander of the sanjak (modern: sancak)- the administrative unit area). When the Bosnian Pashaluk (beylerbeylik, eyalet, ajalet) was established in 1580 , the Pashaluk headquarters was located in Banja Luka. Prior to 1587, a tophana (arsenal) was also built and which was later turned into a fortress, during the reign of Sultan Mehmed III (1595-1603) and, unlike the Old Town in Gornji Šeher, it was called the New City. As usual, a mosque was built in the fort and was dedicated to the Sultan. During the reconstruction of $\mathrm{Nu}-$ man - pasha Ćuprilić (1712 - 1714), the fortress reaches its final dimensions; it was repaired during the period $1737-1738$. From an anonymous description written around 1785 , there were 50 cannons in the fort. The last repair of the Fortress was in I868. During the Austrian occupation, a battalion was stationed in the fort. After World War II, until 1959, Kastel fortress continued to serve military purposes and from the 1960 s onwards, it was used for various purposes. 
The first archaeological discoveries date from 1895 and 1924 , when the votive ara of the consular beneficiary pannoniae sup., together with one more inscription was found along the right bank of the Crkvena river, at the foot of the fort (Patsch, I895). However, the first sondage excavations were undertaken in the period 1971-1974 at the site of Courtyard III, while successive excavations were conducted in all parts of the Kastel site from 1980 to 1988 (Čermošnik 1972; 1973; Žeravica 1973; 1974; 1983; 1984). The entire series of wall structures and objects from the 16 th, 17 th and 18 th centuries have been excavated or determined, such as the foundations of military structures, underground passages and rooms, sewage system, coastal ramparts along Vrbas, fortress parts towards the neighbourhood, circular protective ramparts, part of the smaller and larger ditch, large water tank, etc. The test excavations in Courtyard II (central space) identified very well preserved remains of a late antique building of larger dimensions, for which researchers remain uncertain of its inter- pretation, whether it was a late antique basilica, an administrative building or a complex of various contents, mainly because the research has not been completed. All discoveries made so far, their significance and their largesize, even then indicated the need for further research (Graljuk I980; 1983; 1986; 1988).

\section{Preliminary report of works undertaken in 2019}

At the end of 2018, we began with preparations to continue excavations at the Kastel fortress site in Banja Luka. The first phase included the necessary preparations for geophysical survey: the survey of the entire Kastel site to determine the current state, the choice of method of the geophysical research and how to apply it. On that occasion, it was determined that radar recording should be used at the Kastel site, and that the recording should be done in stages according to the needs of the reconstruction and conservation of the existing fortification facilities. In order to make a detailed study, it was necessary

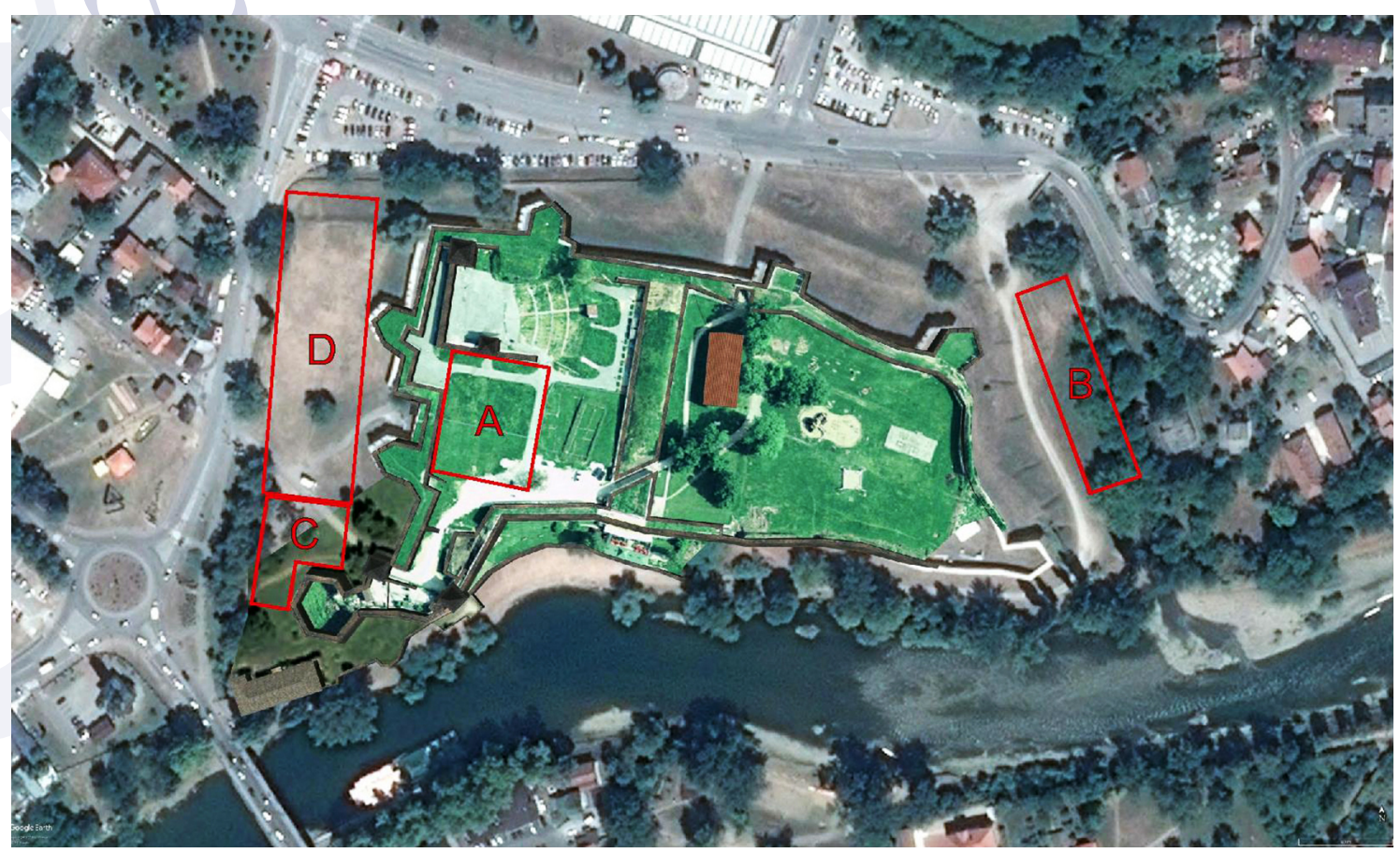

Figure 2 Area of the site researched by geophysical methods. 


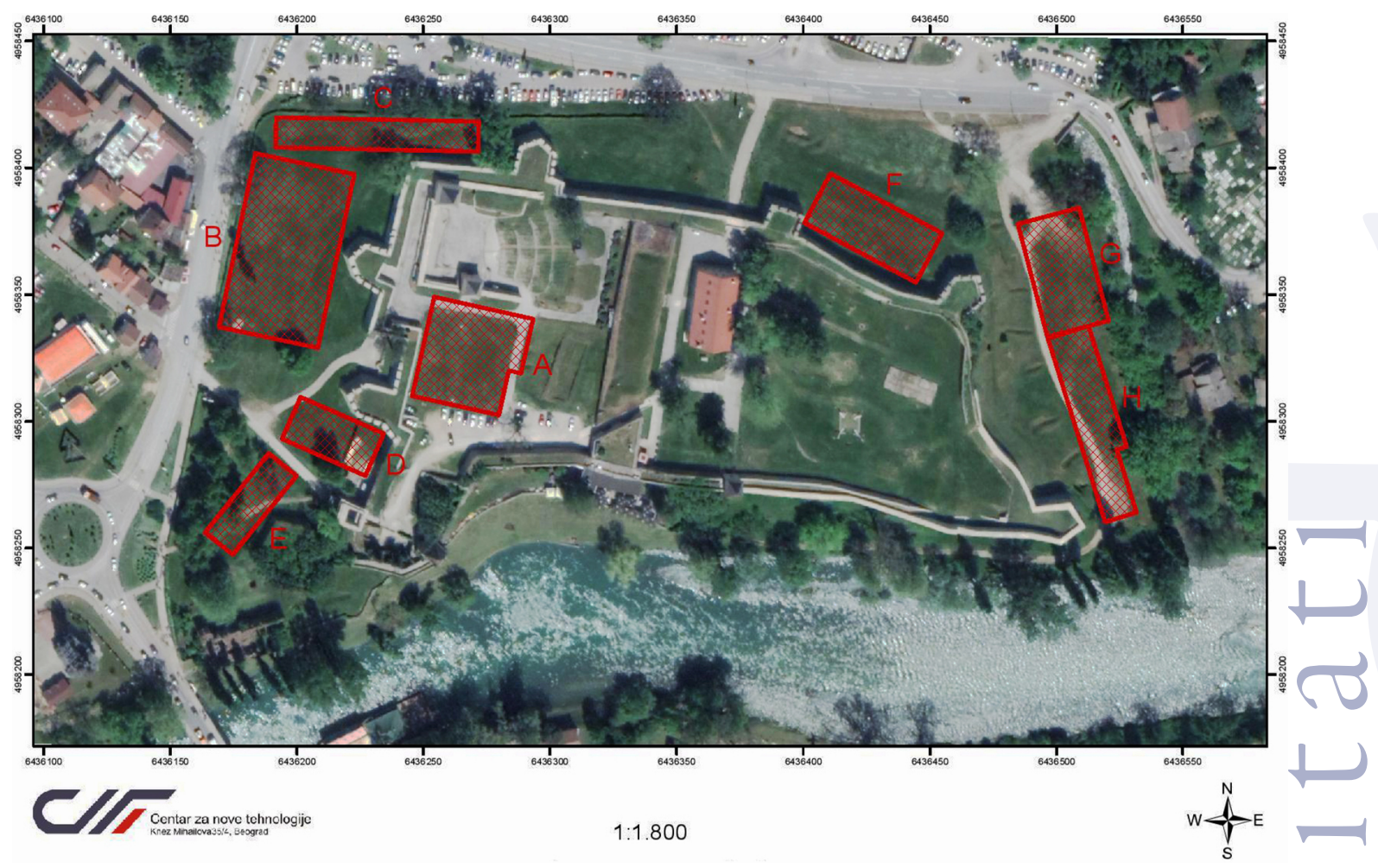

Figure 3 Position of the research fields (from A to $\mathrm{H}$ ).

to prepare all the existing documentation such as geo-referenced geodetic base in digital form, geo-referenced aerial photographs, published papers as well as all documentation from archaeological research carried out so far on the site, etc. This initial phase of the work was done as part of the project "Application of modern methodology in archaeology (study case: Kastel Banja Luka site)", implemented by the Association of Archaeologists of the Republic of Srpska in cooperation with the PI Museum of the Republic of Srpska, the Centre for New Technologies Viminacium Belgrade. The implementation included both the recording of the Kastel site by geophysical methods (Figure 2) and the cleaning of the foundations excavated in period $1984-1988$, within the ramparts of Courtyard II site, which have not been adequately maintained and have over the last 30 years practically become "invisible" under the growth.

\section{Geophysical testing}

Geophysical research conducted by the team of the "Centre for New Technologies Viminacijum" from Belgrade as part of the first phase of the Kastel site excavations in Banja Luka, was performed using the geo-radar method (GPR), which allows detailed coverage of the terrain in order to detect and discover any remains of material culture. The research methodology involved the application of a high-resolution geo-radar method with a antenna, suitable for use in conditions presented at the survey sites. The research was carried out within the framework of the projected rectangular grid, where the dimensions of the survey fields were adapted to the conditions in the field. The Georadar (GPR) method was applied using a $270 \mathrm{MHz}$ antenna, along parallel profiles at a distance of 0.5

The geophysical recording project was implemented by Vladimir Miletic, Igor Milosevic, Zeljko Jovanovic and Jelena Miletic from the Center for New Technologies Viminacium Belgrade. 


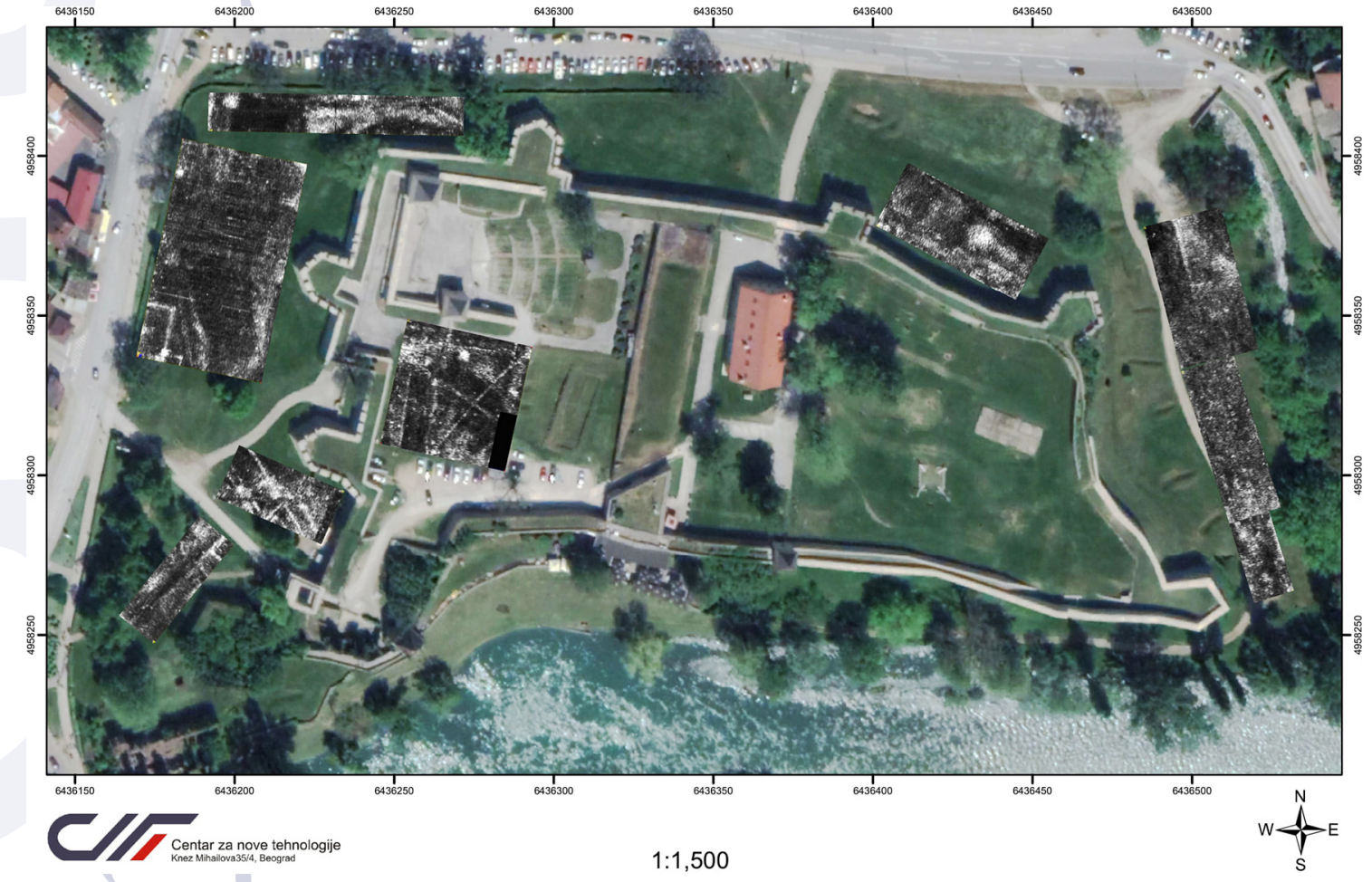

Figure 4 Geophysical research results in the form of electromagnetic anomaly maps.

$\mathrm{m}$ and with a resolution of data for every $0.02 \mathrm{~m}$ GPR profile. Recording time was 64 ns (depth of about $3 \mathrm{~m}$ ). The antenna made direct contact with the ground during the acquisition. The research was carried out in the framework of 8 research fields (from $\mathrm{A}$ to $\mathrm{H}$ ), and the arrangement of these research fields is given in Figure 3.

Geophysical research results are presented in the form of electromagnetic anomaly maps (Figure 4). Electromagnetic anomaly maps are the product of processing all registered geo-radar profiles, generating ${ }_{3} \mathrm{D}$ models and then extracting horizontal sections at multiple depth levels. In this case, the depth levels were $30 \mathrm{~cm}$, $100 \mathrm{~cm}, 130 \mathrm{~cm}, 170 \mathrm{~cm}, 210 \mathrm{~cm}$ and $320 \mathrm{~cm}$. When defining the depth grip, an average velocity of propagation of electromagnetic waves of Io $\mathrm{cm} / \mathrm{ns}$ was taken. For example, in Figure 4 , at a depth of $170 \mathrm{~cm}$, homogeneous soil is represented in black, while anomalous values are shown in light shades. Anomalous value means inhomogeneities in the soil which can be caused by the presence of stone, binder material, burials filled with different material, parts of buildings, etc. These anomalies cause increased values of the amplitudes of electromagnetic waves, shown with light shades on the map. Looking at the results of this survey, we can generally conclude that anomalous values of the electromagnetic field (light shades) are observed in each of the survey fields, which indicate the heterogeneity of the ground subsurface and the clear presence of underground objects or infrastructure.

More pronounced anomalies are found on the west side of Kastel site (researched fields B, C, D and E; Figures 3, 5), as well as inside the Kastel (researched field A; figures 3, 5) where anomalies (light shades in the annexes) are observed in shape and geometry and may be caused by the existence of remains of buildings in the subsurface part of the soil. On the east side of Kastel (researched fields G and H; Figures 3, 5) is noticeable the absence of geometric shaped anomalies (which we expected), implying that 

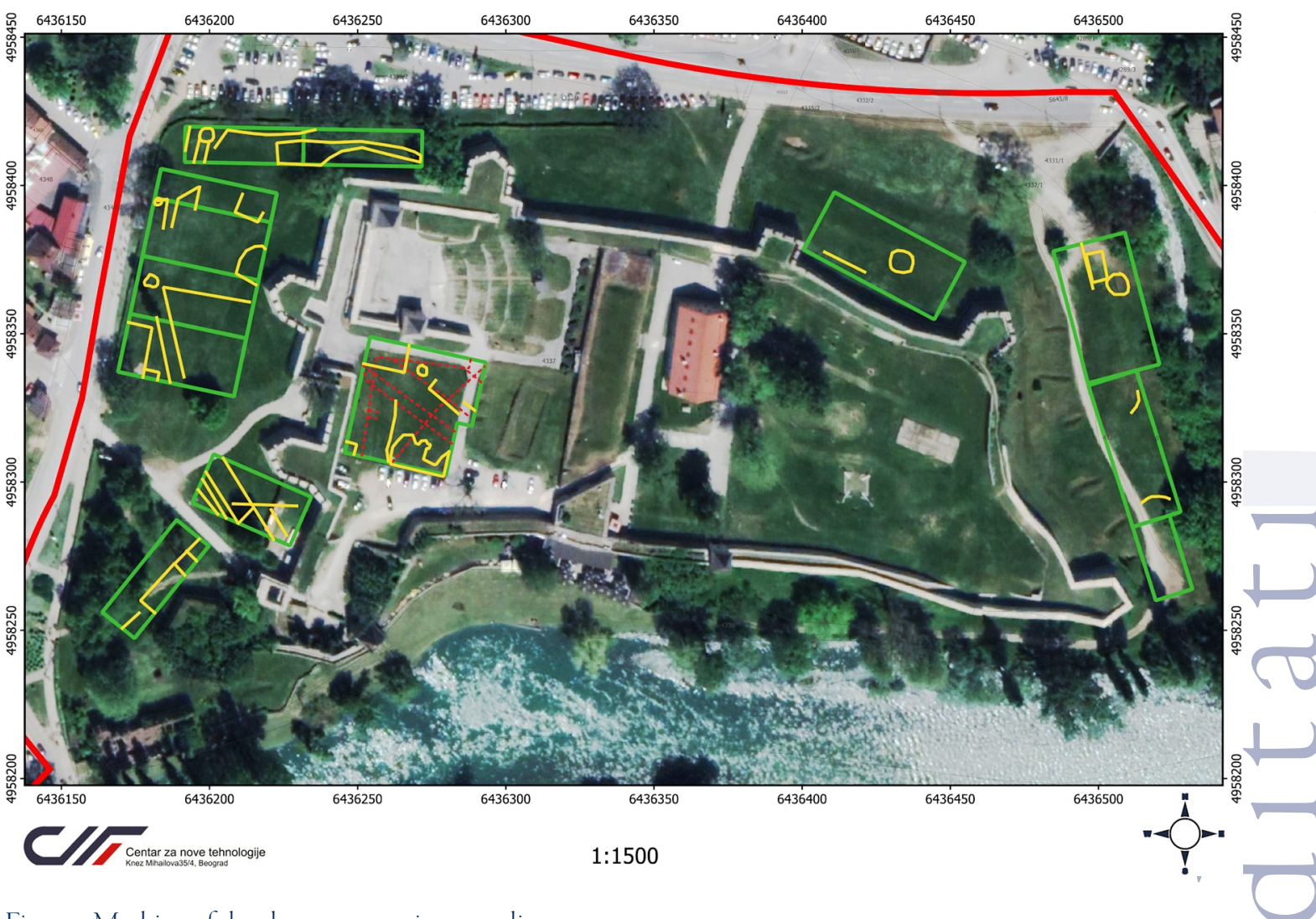

Figure 5 Marking of the electromagnetic anomalies.

the east side of Kastel was probably susceptible to erosion or other types of devastation, as a probable explanation for the lack of any stratigraphically defined occupation horizon. Also, the most pronounced anomalies are located in the north of the investigated field G (Figures 3, $5)$, at a depth of more than $2 \mathrm{~m}$, which lead us to the conclusion that this part of the site is filled with recent material and that the possible presence of buildings can be observed only at greater depths. The interpretation of the results was done by marking the electromagnetic anomalies in Figure 5, where the yellow line indicates some of the anomalies that may be caused by the existence og buildings below the ground surface, and the red dashed line indicates the line structures assumed to correspond to contemporary underground installations.

\section{Research on the courtyard II inside Kastel}

Alongside the geophysical survey and research, we begun to work on cleaning the Courtyard II site within the walls of the ramparts. The last works at this site were completed in 1988 and since then it has been abandoned.; Over time it even served as a soil and overburden disposal area for works undertaken at Kastel. During the spring work ${ }^{2}$ at the Courtyard II site, the eastern part of the building was cleaned, starting from its northeast side. The cleaning was carried out according to the already defined rooms, which we marked with Arabic numerals I to 9, moving from the north-western room as the initial one towards the south (Drawing I). The top layer from 0.20 to $0.30 \mathrm{~m}$ was evenly removed, while in the southern part in room $\mathrm{P}_{7}$ the thick-

2 In addition to the authors, at the excavation also paritcipated: Goran Kalinic (archaeologist), Borisic Radic (archaeologist), Aleksandar Milekic (archeologist), and Jugoslav Jeftic (assistant worker). 

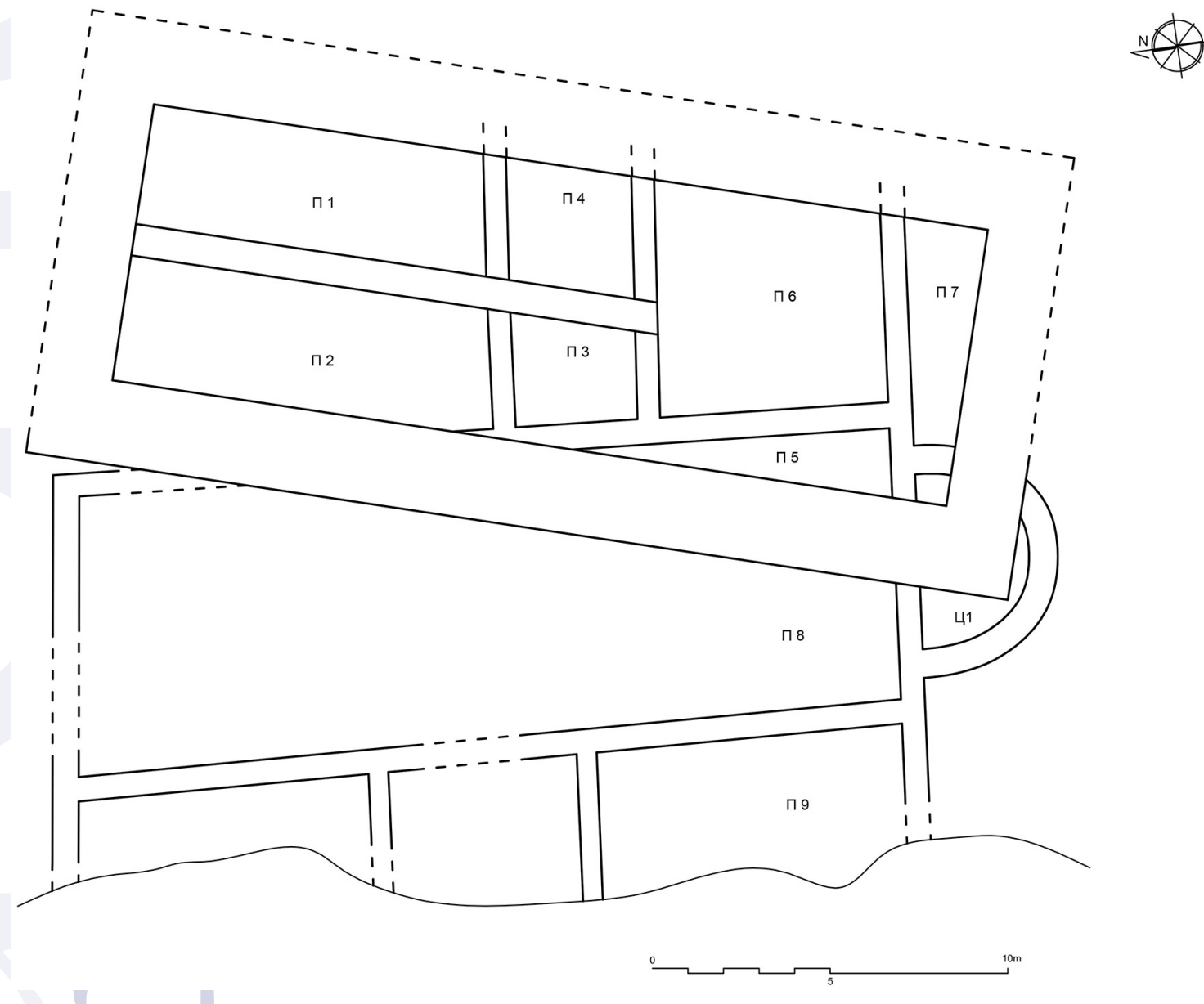

Drawing I Micro-locations researched in 2019 (By Bojan Popovic, architect).

est layer of soil was deposited, and in order to obtain approximately the same level with other parts, about $0.50 \mathrm{~m}$ of soil was removed. To determine the depth of the foundations, two control trenches (KRI and $\mathrm{KR}_{2}$ ) were opened, one trench for each of the building it was observed that the foundations of the older (late antique?) wall in the northeast corner of the western part of the building is at a depth of about $0.50 \mathrm{~m}$ relative to the top of the wall, while the depth of the later (medieval?) wall, measured from the west side of its central part, is about I.50m deep. During this phase of work, a total of 282 artefacts were collected, of which $25 \mathrm{I}$ were pottery fragments, $\mathrm{I}_{3}$ flint and 18 findings classified as "other" (coin, wedges, bullets, etc.). The material was washed and stored in the depot of the Museum of RS.

The second phase of field works at the Kastel site was realized in the period from October 28 to November 2, 2019, also by the Association of Archaeologists of the Republic of Srpska and the PI Museum of the Republic of Srpska, in cooperation with the Faculty of Philosophy University of Banja Luka ${ }^{3}$, the Faculty of Philosophy University of East Sarajevo ${ }^{4}$. This stage of

Students of the History department, Faculty of Philosophy University of Banja Luka: Neven Rogic, Danilo Ratkovic, Dejan Krkeljas, Nikolina Blagojevic, Bojan Cosic, Goran Kremenovic, Ivona Sever, Goran Bozic, Mladen Niksic, Stefan Vuksic.

4 Students of the History and archeology department, Faculty of Philosophy, University of East Sarajevo: Milica Subasic, Bogdan Lazic, Igor Drasko, Milica Lazovic, Luka Bojanic, Milos Nikolic. 


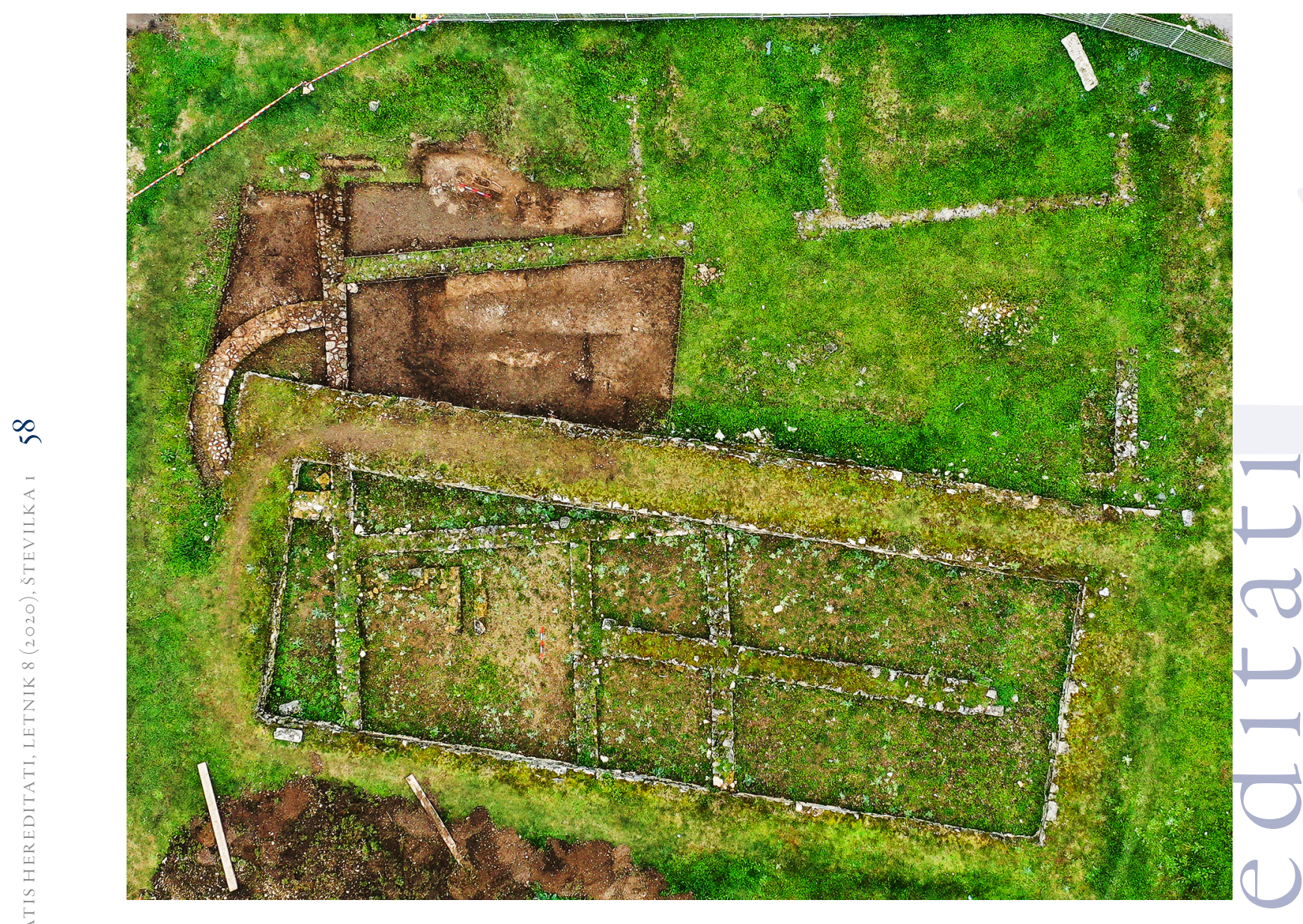

Figure 6 Micro-locations researched in 2019 (Photo by Aleksandar Čavić).

research was organized in the form of a School of Archaeology. The project represents continuation of the cleaning of the Courtyard II site, which began in March of the same year, which carried on with the previously mentioned works of cleaning the site explored in the late 1980 os.

The realization of the project as a School of Archaeology was conceived as a process of field education for students from the above faculties. In addition to the fieldwork during the day, there were a series of public lectures organized in the afternoon at the Museum of the Republic of Srpska for both students and the staff of Republic and City institutions dealing with cultural heritage, as well as those in the non-governmental sector. The project was attended by employees of the Museum of RS, members of the As- sociation of Archaeologists RS, professors and assistants of both universities and 13 students of the History Department from Banja Luka and six students of the History and Archaeology Department from Pale. A substantial number of artefacts was collected in the field, which is stored in the Museum's depot after washing. The analysis of materials from the 2019 season will be done subsequently in cooperation with colleagues from the Faculty of Humanities, University of Primorska, Slovenia.

During this field season, the works were carried out in parallel at three micro-locations of the western part of the building, in rooms 8 and 9 , and in zone I (inner zone of the apse) as well as the outer space around the apse (Figure 6; Drawing I). The work began with the remov- 


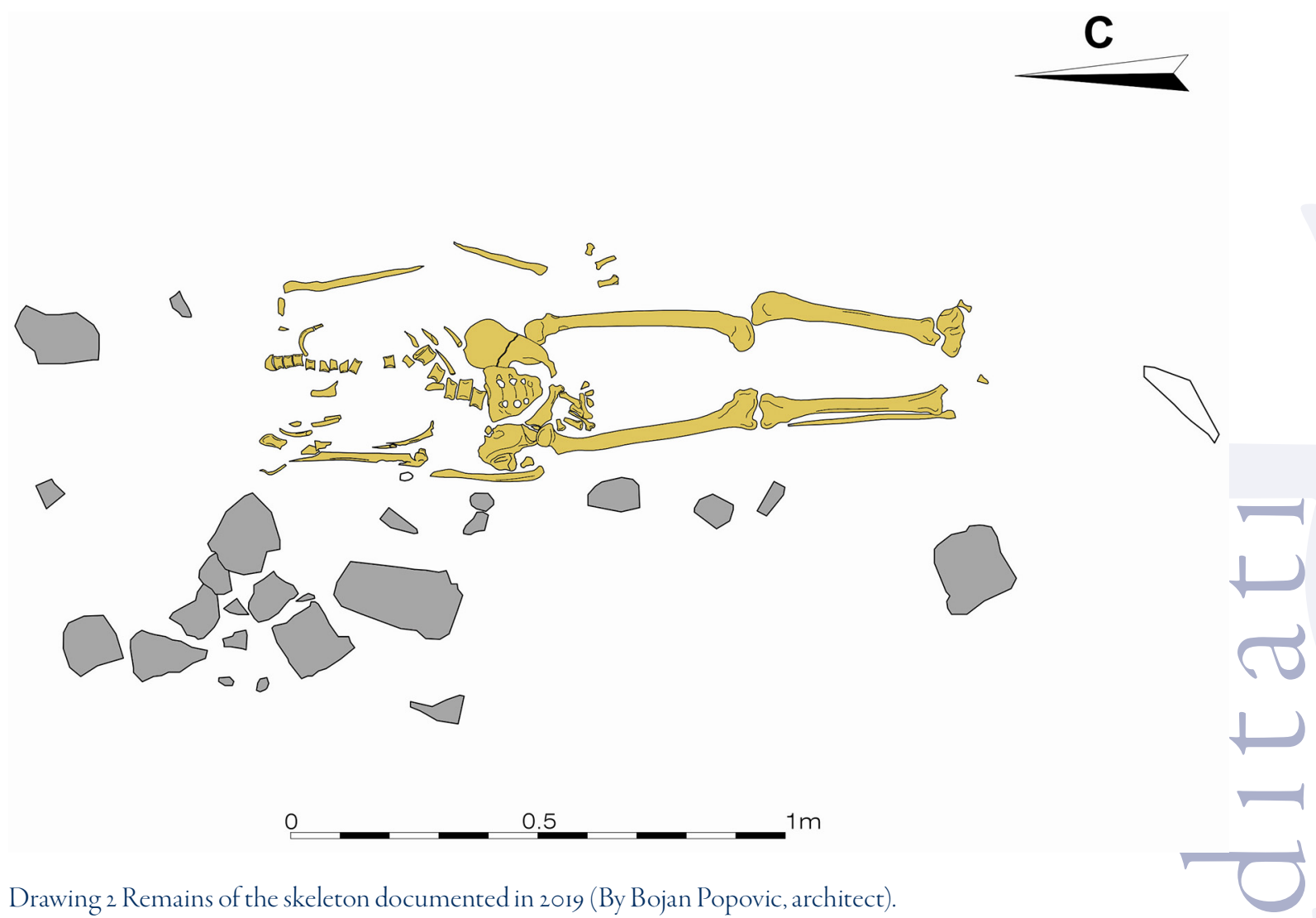

the cadastre of underground installations as well as previous archaeological research has conditioned the interpretation of the results, which is for the time being limited only to the separation of geometrically regular anomalies shown in Figure 5, and which should be considered when planning future research or performing any other work. Based on the results from Courtyard II site, where the current revision archaeological research is in progress, a large number of line anomalies are visible in the exploration field $\mathrm{A}$ (Figure 5), extending at depths of $0.30 \mathrm{~m}$ to 1.70 $\mathrm{m}$. Most of these anomalies can be assumed, on the basis of geometry, to correspond to underground installations (red dashed lines). The remaining anomalies (yellow solid lines) can be assumed to correspond to parts of fetures below the ground surface. A zone with elevated electromagnetic wave amplitudes is observed in the southeast corner of researched field A which may correspond to the presence of a larger amount of the construction waste and other constructing material. A circular anomaly stands out at the depth of about $1.70 \mathrm{~m}$ in the northern part of the researched area, which could be appropriate for a pit or burial. The remaining line anomalies within this investigated field possibly correspond to parts of buildings below the ground surface.

As for the continuation of the archaeological work, during the next phase it is planned to complete the excavation in the northwest part of the building at the Courtyard II site. In accordance with the above geophysical survey results, it is planned to extend the excavation to the west, which implies the removal of the existing fence and asphalt access to the summer theatre space as well as providing an alternative route to the same. At the moment, the preparation of the plan and the plan of conservation and restoration works of the existing and future foundations are in progress, in cooperation with the Republic Institute for the Protection of the Cul- 
tural, Historical and Natural Heritage of Republic of Srpska. All archaeological works so far are co-financed by the City of Banja Luka through public calls for projects of cultural and artistic creativity co-financing. As much as it was capable of supporting this, for the last two years the City of Banja Luka provided finances for the reconstruction and reconstruction of the walls of Kastel fortress, as well parts of the entrance tower have been reconstructed so far as well as the southern ramparts of the fort, and work is continuing into the current year.

\section{Povzetek}

Konec leta 2018 so se začele priprave na nadaljevanje raziskav na trdnjavi Kastel v Banji Luki ter se končno začele leta 2019. Prya faza je vključevala geofizični radarski posnetek $10.000 \mathrm{~m}^{2}$ ter obdelavo pridobljenih podatkov. Rezultati so na vsem raziskovanem območju pokazali jasne znake, da je pod površjem pričakovati različne arheološke strukture. Pomanjkanje informacij iz katastra podzemnih vodov in predhodnih arheoloških izkopavanj je pogojevalo razlago pridobljenih podatkov. Pridobljene podatke smo omejili na izolacijo geometrično pravilnih nepravilnosti, ki jih je treba upoštevati pri načrtovanju prihodnjih raziskav ali izvajanju del katere koli vrste.

Vzporedno z geofizičnimi raziskavami smo začeli čiščenje arheološkega najdišča na Dvorišču II znotraj zidov okopa. Gre za nadaljevanje izkopavanj kompleksa stavb iz poznoantičnega (?) in srednjeveškega (?) obdobja, ki so jih leta 1988 ustavili. Od tedaj je bilo najdišče zapuščeno in prepuščeno propadanju. Ciščenje je potekalo po že opredeljenih prostorih, ki smo jih označiliz arabskimi številkami i do 8, ter se začelo v severozahodnem delu in potekalo proti jugu. Po odstranitvi vegetacijske plasti debeline od 0,20 do $0,50 \mathrm{~m}$ smo odprli dva kontrolna jarka za določitev globine temeljev zidov vsake stavbe. Dela so se nadaljevala v zahodnem delu stavbe, razdeljenem na tri mikrolokacije, kjer je bila odstranjena tudi plast debeline od o,10 do o,30 m. Poleg številnih nedavnih najdb ter živalskih kosti, keramičnih fragmentov in kamnitih prodnikov sta bili v prostoru 9 vzdolž zahodnega profila A-D odkriti dve človeški okostji. Do konca raziskav je bilo eno okostje v celoti očiščeno, dokumentirano in odstranjeno, drugo pa je ostalo za nadaljevanje raziskav. Na zahodnem delu najdišča je bila odkrita površina, ki najverjetneje predstavlja negativ zidu, na katero se nadaljuje plast s kamni in malto. Najverjetneje gre za podkonstrukcijo poda, ki jo seka plast temnejše zemlje, kar kaže na možnost pokopa. Najverjetneje gre za objekt, ki so ga poškodovali kasnejši vkopi.

$\mathrm{V}$ naslednji fazi se $\mathrm{v}$ skladu z rezultati geofizičnih raziskav načrtuje zaključek izkopavanj na severozahodnem delu stavbe na Dvorišču II. Poteka pa tudi izdelava načrta konservatorsko-restavratorskih del na temeljih, kot tudi predstavitev celotnega najdišča.

\section{Summary}

At the end of 2018 preparations began to continue the excavations at the Kastel fortress site in Banja Luka, which eventually started in 2019. The first phase of the work involved geophysical radar recording of $10,000 \mathrm{~m}^{2}$ as well as the processing of the obtained data, which stated that in all the researched area there are clear indications, that different archaeological objects should be expected below the surface. The lack of information from the cadastre of underground installations and previous archaeological excavations has conditioned the interpretation of the obtained data. We limited the obtained data on isolation of geometrically correct anomalies, which should be taken into account when planning the future research or performing works of any type.

In parallel with the geophysical research, we began cleaning of archaeological site in the Courtyard II within the walls of the rampart. It is considered as the continuation of the excavations of the Late-antique (?) and Medieval (?) complex of buildings, which were discontinued in 1988 since the site was abandoned and left to chance. Cleaning was carried out according to the already defined rooms, which we marked with Arabic numerals i to 8, moving from the northwestern room towards the initial south. After removal of the vegetation layer from 0.20 to $0.50 \mathrm{~m}$ of the newly formed deposition layer, two control trenches were opened to determine the depth of the foundation zone of the wall from each of the objects. The work continued in the western part of the building divided the three micro-sites where a layer of $0.10-0.30 \mathrm{~m}$ was also removed. In addition to a number of recent findings, as well as animal bones, ceramic fragments and stone pebbles, two human skeletons were identified in room 9 along the western A-D 
profile. By the end of the excavation period, one skeleton was fully cleaned, documented and removed from the site while the other was left for next excavation season. In the western part of the site, the surface that most likely represents the negative of the wall was noted to which the layer of stone and mortar is continued. Most likely it is a substructure of the floor intersected by a layer of darker earth, which gives the possibility of burial.

As a next phase, the completion of excavations in the northwestern part of the building at the Courtyard II is planned, in accordance with the results of geophysical research, and a plan of conservation and restoration works of the foundation is underway, as well as the presentation of the entire site.

\section{References}

Bojanovski, I. 1977. »Bosanska Posavina u antici u svjetlu novih istraživanja.« $\mathrm{U}$ Antički gradovi i naselja u južnoj Panoniji i graničnim područjima, ur. B. Vikić Belanćić, I 47-54. Beograd; Varaždin: Antička sekcija SADJ - Hrvatsko arheološko društvo - Gradski muzej u Varaždinu.

Čremošnik, I. 1972. »Kastel, Banja Luka gradina sa slojevima od praistorije do danas.« Arheološki pregled 14: 133-34.

Čremošnik, I. 1973. »Otkriveno slovensko gradinsko naselje u Kastelu u Banja Luci.« U Zbornik krajiskih muzeja $V$, 193-95. Banja Luka.

Graljuk, B. 1980. »Pećine - Klašnice - Banja Luka, Paleoitska stanica.«Arheološki pregled 2I: 9-15

Graljuk B., 1983. »Novija arheološka otkrića $\mathrm{i}$ ispitivanja na području Banja Luke i okolice.«U Zbornik I, Arheološka problematika Zapadne Bosne, 23-40. Sarajevo: Arheološko društvo Bosne i Hercegovine.

Graljuk, B. 1986. »Banja Luka/Kastel.«U Arheološki pregled (za I985. godinu), 136-37. Ljubljana.

Graljuk, B. 1988. Io godina arheoloških istraživanja područja Banjaluke i okoline 1978-1988, katalog izložbe. Banja Luka.
Husedžinović, S. 2005. Dokumenti opstanka. Zenica: Muzej grada Zenica.

Patsch, C. I895. »Epigrafski nagođaji iz godine 1985.« Glasnik Zemaljskog muzeja VII, I895, 573-86; 1895a, 574-77.

Skarić, V. 1924. »Banja Luka i njena okolina u davnini.«Otadžbina, I924, br. 31-33, 2; 3; 2.

Ševo, Lj. 1996. Banjolučka tvrdava Kastel, istorijski pregled i ocjena postoječeg stanja, 1996, 69-80.

Žeravica, L. 1973. »Kastel - Banja Luka, kompleksno utvrđenje.« Arheološki pregled I5: II2-I3.

Žeravica, L. 1974. »Kastel - Banja Luka, višeslojni naselje unutar turskog utvrđenja.« Arheološki pregled I6: I29.

Žeravica, Z. 1983. »Ostaci badenskog naselja na Kastelu u Banjoj Luci.«U Zbornik Arheološkog društva BiH I, 4I-53, Sarajevo: Arheološko društvo Bosne i Hercegovine.

Žeravica, Z., in L. Žeravica. 1984. »Arheološka istraživanja na Kastelu u Banjaluci.«Naše starine XVI-XVII: 19-45.

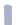
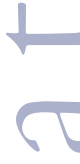
1

$$
\text { r }
$$

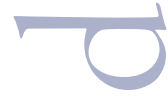

( 